\title{
Impact Regional Autonomy in Improving Public Services Quality
}

\author{
Heru Rochmansjah \\ Institut Pemerintahan Dalam Negeri (IPDN), Indonesia \\ Email: heru_rochmansjah@ipdn.ac.id
}

\begin{abstract}
Public service quality and many other aspects are still far from expectations, especially public autonomy. More government work needs to be done by finding more solutions, such as revitalization, reorganization, deregulation, and increasing the professionalism of officials and personnel involved in work, including rewards and sanctions for public services. This effort can be achieved when each unit works together, which impacts the improvement of public service quality.
\end{abstract}

Keywords: Quality, Public Services, Regional Autonomy.

\section{A. INTRODUCTION}

As a continuation of the political reform agenda launched in 1998, the implementation of regional autonomy must be recognized as a failure to bring meaningful improvements in life for most Indonesians. The public's desire to be an efficient, responsive, and responsible civil servant has not yet been fully realized, because the ongoing political reforms have not followed efforts Improving the standard of public service. In almost every public service unit, it is still easy to find various corrupt practices in public service management, such as service uncertainty, illegal taxation, and the disregard for the rights and dignity of citizens who use services (Hendrayadi, 2011). Because changes in political life do not affect public service quality, Undoubtedly, this situation is sad. The aspirations of the national autonomy group to increase the standard of public services are far from reality.

The 2002 Governance and Decentralization Survey conducted by PSKK UGM found that the public service system provision in regencies/cities in Indonesia continues to be full of uncertainties regarding prices, period, and manner of operation. Managing public services is like entering a wilderness full of uncertainly. Service time and costs have never been precise for service users. This happens because the service procedure never regulates the obligations of the service provider and the rights of citizens as users. Procedures tend only to regulate citizens' obligations when dealing with service units. This very high uncertainty prompts residents to pay extortion fees to officers so that service certainty can be obtained immediately. Uncertainty can also 
encourage citizens to choose to use a service bureau to complete their services rather than settling them themselves.

Besides uncertainty, another problem that is easily found in almost every public service is service discrimination. Bureaucratic officials even acknowledging that they always consider the factors of friendship, political affiliation, ethnicity, and religion in the delivery of services. NGO activists involved in the 2002 GDS survey even showed worse service discrimination practices than described by bureaucratic officials. According to ethnicity and religion, discrimination tends to worsen outside Java-Bali than in Java-Bali (Setyobudi, 2016 ). This can be easily understood by centralistic government policies that have tended to make people and ethnicity in the regions feel marginalized. Therefore they use regional autonomy as an opportunity to fight for the interests of indigenous people and certain ethnicities in government. This finding is und oubtedly very alarming because discrimination of services on any grounds is one of the most fundamental violations of citizens' rights.

Seeing how complicated the problems in the field of public service delivery are, attempts to increase the standard of public services in Indonesia inevitably involve systemic, systemic reforms that focus on all aspects of the government bureaucracy problems. The problem now is what attempts should be taken in the age of regional autonomy to enhance the efficiency of the public services? Changes that are peace-meal tend to be ineffective because changes that occur in one aspect will be co-opted with problems that occur in other aspects. Efforts to increase the standard of public services can only be effective if substantial and meaningful reforms are brought in. These changes must include revitalization, reform, and legalization, enhancing the professionalism of officials and community participation, corporatization, e-government, granting community service unit awards, and sanctions. Only by promoting systemic reform and drawing upon all aspects of the public service issue would it be possible to increase the efficiency of public services, in turn by increasing the degree of public trust in the government.

\section{B. METHOD}

The research methodology utilizes methodological approaches in accordance with the research objectives that strive to clarify, evaluate, examine, and investigate the standard of public services in the era of regional autonomy. The qualitative research process by researchers is done by conducting a literature study following the topic (Primary Data) of the research to explore views, ideas, ideas, and facts about the research topic so that the data and information are grouped, coded, truthfully triangulated and analyzed throughout the research process. 


\section{RESULTS AND DISCUSSION}

The anticipated effects of regional autonomy involve delivering more fulfilling public facilities, welcoming citizen involvement, growing the pressure on central government, increasing regional flexibility and sophistication, and planning projects more in line with national needs (Hook, 1991). In this situation, national autonomy is seen as a reflection of the democratic will to enhance public infrastructure (Hardiyansyah 2018). Regional autonomy is also recognized as a necessary principle for an efficient government (Duchacek, 1986). As a consequence, the government has to be taken back to the population, so that the programs it offers are getting improved (the stronger the government, the higher the service).

According to political theory, one way to get democracy back to the people is to introduce a decentralization program Duchacek, (1986). The decentralization policy (regional autonomy) which was rolled out on January 1, 2001, as a manifestation of the mandate of Law Number 22 of 1999 (now Law Number 32 of 2004) concerning Regional Government, which has extended the authority of regional governments, the regional governments want to do not want to have to be able to carry out various authorities that have been carried out by the central government, along with the services that must be provided. This provision of autonomy, in terms of service, is seen as one of the efforts to cut bureaucratic barriers, which often provides extended and high-cost services. Public councils are also called upon to be more positioned to deliver good quality infrastructure in the context that they are more geared towards the needs of the people.

It can be shown that the propensity of reduced output in public service bureaucracies is affected by a culture in paternalism that is still high, which induces bureaucrats to be more power-oriented than task-oriented, places themselves as bosses, and views (public) task consumers as subjects of obligation that need their support. The weak output of the public service bureaucracies, according to Prasodjo \& Kurniawan (2008) is also attributed to a power-sharing structure that continues to concentrate on leadership such that subordinates who are closely connected to service consumers frequently do not have the necessary authority to react to the complexities of service delivery.

As a consequence, the output of government institutions has been at the forefront, especially after the advent of a more democratic policy environment. People who have started asking should be the interest they earn for services rendered by government entities (Sofyan \& Akbar, 2013). On the other hand, a case revealed by Mulyadi (2016) is also often seen and heard the actions and behavior of unscrupulous, unfriendly, discriminatory service providers, service systems that have not been transparent, convoluted and do not guarantee certainty, both time and the cost. 
In this context, many attempts should be made to increase the efficiency of public services, including:

1. Revitalization, privatization, and redistribution of state services;

2. Boost the integrity of civil servants;

3. Corporation of civil sector entities;

4. Creation and usage of digital government (e-government) by civil sector agencies;

5. Enhanced involvement of the population in public services;

6. They are awarding rewards and penalties to the Civic Service Groups.

The first step in enhancing the efficiency of public services is the revitalization, privatization, and redistribution of public utilities. It is achieved by shifting the place and function (revitalizing) of administration in the delivery of services to the public. Those who like to control and rule change to those who like to serve, to those who like to use a power strategy, change to be helpful in a versatile, collaborative path, and slogans for a practical way of working (Winarno, 2002). In this context, Rohkim (2013 ) emphasized that public bureaucracy should not give priority to authority, but that the position of the public servant should be prioritized.

Institutional reform by the creation of appropriate organizations is another crucial component of enhancing public services (Hikam, 2018). The right type of organization (rightsizing) can be interpreted as an attempt to reduce government bureaucracy to create organizations that are more proportionate, flat, open, short-term bureaucratic, and decentralized. The role of public service organizations would be more proportionate, productive, and profitable and backed by high-quality human capital. This will happen if elected authorities are committed to the four standards of service quality: reliability, surprise, recovery, and justice (Stone \& Ward, 2000). Reliability is related to the reliability and quality of the services. This involves the fulfillment of the will to commit. The consistency of the services should depend on and is generally assessed by the TERRA concept, which stands for service quality components, including tangible, empathy, reliability, responsiveness, and assurance.

Tangibles are the appearance of physical structures, equipment, staff, and communications resources. Empathy is the attitude of understanding, providing service, and attention to the public. Reliability is the ability to deliver reliable and accurate services according to promises. Responsiveness is responsiveness in providing services to the public. In contrast, assurance is knowledge, friendliness, politeness, and the ability to build public trust.

While surprise is a way to achieve a situation where public customers feel a positive surprise for the services provided, this feeling or state comes from something that is obtained beyond his expectations. Service recovery is an organization's strategy to regain lost or declining public trust because it has experienced disappointment over 
poor service quality. Furthermore, fairness is the principle in providing services to the limits following ethics, the applicable provisions.

In this regard, the institutional restructuring and repositioning of official public positions, are arranged with the principle of lean but rich in function, and place employees in the office, based on the results of the fit and proper test, as well as the relevant experience. Not based on taste like and dislike.

Before the revitalization and institutional restructuring are carried out, the first step that must be taken is deregulation, by reviewing and perfecting the statutory regulations which underlie service delivery in various Local Government Agencies to be more adapted to the aspirations of reform by cutting down various barriers that make it simpler/efficient and shortening long bureaucratic pathways to facilitate and smooth service delivery. In this effort, among others, including through the setting of various service standards, institutional simplification, and control range.

The next step towards improving the quality of public service is to increase the professionalism of public service officials. The steps that must be taken to improve the professionalism of service providers include:

1. Conduct a study/analysis of the need for functional and practical technical training by the central government and regional governments;

2. Establish authority for the implementation of functional technical education and training Between the federal government, the provincial government and the district/city administration;

3. Seek to develop functional positions in the field of public services; and

4. Conduct a comparative study of the public service delivery system (Yunus, 2002).

Efforts to improve public service quality can also be made through the corporatization of public service units. Management autonomy policy (corporatization), namely, gives explicit and apparent authority to specific units/work units of Government Agencies to independently and autonomously carry out operational management services. The policy is intended to build and improve government organizational units' performance to provide excellent service and choose competitive advantages, especially for work units that carry out community service functions. This step of corporatization must undoubtedly be followed by various changes and adjustments to the system and management of the service units, including changes in the organization's values and work culture.

The management autonomy policy was initiated by the government since 1991 through the "Self-Unit Unit" policy as stipulated in Presidential Decree Number 38 of 1991 concerning the Self-Funding Unit and Procedures for Financial Management. This policy gives authority to broader autonomy, specifically the authority to use the functional direct revenue to finance operational services. 
Efforts to enhance the quality of public services are then rendered through the creation and use of the E-Government for public service agencies. In line with the information technology development program in Indonesia, in the government sector, as an application of empowering the state apparatus, the government is increasing and developing the implementation of "E-Government or E-Government Online" in all government organizations, both at the central and regional levels, especially to agencies that provide services to the community, so that the provision of data and information can be accessed and utilized quickly, accurately and safely by the community and other users. With the E-Government application, it is expected that all government organizations' activities can be carried out electronically so that they can be utilized to facilitate decisionmaking for leaders at all levels.

Furthermore, efforts to improve public services' quality can also be made by increasing public participation in public services. In order to ensure transparency and accountability in the delivery of public services by the apparatus, a conception was developed by building community involvement/Engagement in the introduction of public service programs for developing innovation and civic participation in development in addition to the community being able to participate fully and carry out social control (social control). This includes oversight by the legislative body (Regional People's Representative Council).

The steps to increase public participation in public services include:

1. Involve the community / NGOs in evaluating service performance, including by forming Public Service Committees;

2. Following up on public complaints about complaints/suggestions/opinions relating to service delivery;

3. Involving the public in the administration of public services through privatization;

4. Involving community participation in conducting studies/analysis of each determination of government policy in public services;

5. Establish a community satisfaction index; and

6. Counseling about various service policies to the community.

A further important aspect of enhancing the quality of public services is the allocation and sanctioning of community support groups. The demands of the community and the business world towards improving service quality are getting stronger. Thus, it is necessary to support the creation of a conducive business climate, with appropriate, specific, safe, appropriate, and accountable service indicators.

Today's reality is that community service is not going well. Therefore it is necessary to stimulate/stimulate in the form of awarding service units that have been successfully selected into pilot service units and sanctions to service units whose performance is not optimal. 
The purpose of awarding or imposing sanctions includes:

1. Build enthusiasm and encourage the creation of community service delivery units to improve service performance and quality;

2. Growing the principle of accountability and transparency of the apparatus;

3. Motivate service units in improving and improving the quality of service performance;

4. Creating a model of pilot services; and

5. Increase the value of service units (goodwill).

At present, the local government has and is currently drafting various service standards. With the standard, it can be measured how far the performance/performance of services can be assessed. Service standards are provisions on the form, size, and general guidelines for services performed in the service sector. This means that service delivery can determine the type and quality of service based on the authority and ability of each region.

Thus service standards can be a tool to increase the accountability of service providers to the community. People can measure the extent to which service providers can fulfill their obligations to provide community services according to established standards. Service standard also means a form of promise or commitment from leaders and all service providers to provide services following established standards. In order to have a positive effect on enhancing the quality of public service, in the face of disease in the chronically public bureaucracy, it needs to be done: First, wash the brain (brainwash) to indoctrinate thinking clearly and positively to defend truth, justice and the interests of the people; Second, dialysis (blood wash) to clean up corrupt diseases, attitudes and behavior that are not honest, not responsible and so forth; Third, wash your heart (heart wash) to treat illnesses arrogant, self-power, winning itself, grumpy and discriminatory in providing services (Yunus, 2002). If the cleansing of the bureaucratic pathology can be realized, it is believed that it has a significant impact on improving the quality of public services.

\section{CONCLUSION}

Efforts to increase the quality of public services in the age of regional autonomy must be made in an organized way by making a variety of breakthroughs, including by revitalization, privatization, and deregulation, enhancing the professionalism of the apparatus and community participation, corporatization, e-government, giving awards and sanctions to community service units. To ensure all this, control needs to be developed by measuring the satisfaction of public services as a feedback effort to improve the quality of services on an ongoing basis. 


\section{REFERENCES}

1. Duchacek, I. D. (1986). The Territorial Dimension of Politics Within. Among and Across Nations, Boulder, Colo.

2. Hardiyansyah, H. (2018). Kualitas Pelayanan Publik: Konsep, Dimensi, Indikator dan Implementasinya. Gava Media.

3. Hikam, M. A. (2018). Pembentukan Undang-Undang Berdasarkan Program Legislasi NasionaL. Jurnal Legislasi Indonesia, 2(1), 23-30.

4. Hendrayady, A. (2011). Reformasi Administrasi Publik. Jurnal Fisip UMRAH, 1(1), 107-113.

5. Hook, J. R. (1991). Bureaucracy: What Government Agencies Do and Why They Do It. Basic Book.

6. Prasojo, E., \& Kurniawan, T. (2008). Reformasi Birokrasi dan Good Governance: Kasus Best Practices dari Sejumlah Daerah di Indonesia. The 5th International Symposiumof Journal Antropolgi Indonesia.

7. Rokhim, A. (2013). Kewenangan Pemerintahan Dalam Konteks Negara Kesejahteraan (Welfare State). Jurnal Ilmiah Ilmu Hukum Dinamika Hukum, 136.

8. Sofyani, H., \& Akbar, R. (2013). Hubungan faktor internal institusi dan implementasi sistem akuntabilitas kinerja instansi pemerintah (SAKIP) di Pemerintah Daerah. Jurnal Akuntansi dan Keuangan Indonesia, 10(2), 184-205.

9. Stone, C. E., \& Ward, H. H. (2000). Democratic policing: A framework for action. Policing and Society: An International Journal, 10(1), 11-45.

10. Setyobudi, Y. F. (2016). Peran Masyarakat Dalam Pelayanan Publik Sesuai Dengan Undang-Undang No. 25 Tahun 2009 Tentang Pelayanan Publik. Jurnal Dimensi, 2(1).

11. Winarno, B. (2002). Good Governance: Akuntabilitas dan Kontrol Birokrasi. Surabaya: Insani Cendikia.

12. Yunus, Y. (2002). Profesinalisasi Birokrasi dalam Pelayanan Publik. Jurnal Demokrasi, 1(1). 